\title{
Graves' disease coexisted with resistance to thyroid hormone: a case report
}

\author{
Hiroshi Akahori ${ }^{*}$ and Rika Usuda²
}

\begin{abstract}
Background: Resistance to thyroid hormone is a rare autosomal dominant disorder characterized by reduced responsiveness to thyroid hormone and can cause syndrome of inappropriate secretion of thyroid stimulating hormone. Although Graves' disease is a common autoimmune thyroid disorder, the coexistence of these two diseases is extremely rare and makes the diagnosis and treatment complicated, leading to the delayed diagnosis of resistance to thyroid hormone. We describe the case of a Japanese man with resistance to thyroid hormone coexisting with Graves' disease, in which the correct diagnosis of resistance to thyroid hormone was delayed by masking of the signs of syndrome of inappropriate secretion of thyroid stimulating hormone, with final diagnosis 30 years after the initial treatment for Graves' disease.
\end{abstract}

Case presentation: A 30-year-old Japanese man presented with diffuse goiter and thyrotoxicosis. Anti-thyroid stimulating hormone receptor antibody was positive. He was diagnosed with Graves' disease. Anti-thyroid medication was chosen as the initial treatment for Graves' disease. However, this treatment failed to normalize the free triiodothyronine, free thyroxine, and thyroid stimulating hormone levels. His thyroid hormone levels indicated syndrome of inappropriate secretion of thyroid stimulating hormone. After cessation of methimazole treatment by remission of Graves' disease, his state of syndrome of inappropriate secretion of thyroid stimulating hormone persisted. Magnetic resonance imaging revealed no pituitary tumor lesions. The results of thyroid stimulating hormone-releasing hormone stimulation test showed a normal response of thyroid stimulating hormone. He was suspected to have resistance to thyroid hormone. Direct sequencing analysis of the thyroid hormone receptor $\beta$ gene identified a heterozygous missense mutation, R282S. Coexistence of resistance to thyroid hormone with Graves' disease was confirmed. He has no signs of thyrotoxic symptoms, and is capable in activities of daily living at the present time.

Conclusion: We described a rare case of resistance to thyroid hormone simultaneously existing with Graves' disease. This case demonstrated that these diseases can coexist, and indicated some of the difficulties in diagnosis of resistance to thyroid hormone with coexisting Graves' disease. The diagnosis of resistance to thyroid hormone did not become apparent until after anti-hyperthyroidism treatment. Although rare, careful follow-up after the initial treatment of Graves' disease is necessary. The coexistence of these two diseases should be considered in patients showing occasional syndrome of inappropriate secretion of thyroid stimulating hormone.

Keywords: Graves' disease, Resistance to thyroid hormone, Thyroid hormone receptor $\beta$, R282S, Syndrome of inappropriate secretion of TSH

*Correspondence: akahori0606@hotmail.com

${ }^{1}$ Department of Endocrinology and Metabolism, Toyama Prefectural Central Hospital, 2-2-78 Nishinagae, Toyama-shi, Toyama 930-8550, Japan

Full list of author information is available at the end of the article

\section{Background}

Resistance to thyroid hormone (RTH) is an autosomal dominant disorder characterized by reduced responsiveness of variable tissues to thyroid hormone [1,2]. The human thyroid hormone receptor (TR) is expressed by original author(s) and the source, provide a link to the Creative Commons licence, and indicate if changes were made. The images or other third party material in this article are included in the article's Creative Commons licence, unless indicated otherwise in a credit line to the material. If material is not included in the article's Creative Commons licence and your intended use is not permitted by statutory regulation or exceeds the permitted use, you will need to obtain permission directly from the copyright holder. To view a copy of this licence, visit http://creativecommons.org/licenses/by/4.0/. The Creative Commons Public Domain Dedication waiver (http://creativeco mmons.org/publicdomain/zero/1.0/) applies to the data made available in this article, unless otherwise stated in a credit line to the data. 
two genes, $\operatorname{TR} \beta$ and TR $\alpha$, which have several isoforms generated by alternative splicing. TR $\beta 1$ is expressed in the liver, kidney, and brain, while TR $\beta 2$ is expressed in the anterior pituitary and hypothalamus, and is mainly involved in the negative feedback regulation of thyroid stimulating hormone (TSH) by thyroid hormone in the anterior pituitary. RTH is mainly caused by germline mutations of TR $\beta$, localized to the ligand-binding domain [3-5]. The mutant receptors show reduced ligand binding, and inhibit wild-type TR action in a dominant negative manner [6]. This syndrome was first reported by Refetoff et al. in 1967 [7]. The syndrome of inappropriate secretion of TSH (SITSH) showing elevated serum levels of free thyroxine (FT4) and free triiodothyronine (FT3) with normal or slightly elevated TSH levels (non-suppressed TSH) is a hallmark of RTH as well as TSH producing pituitary tumors [8].

Graves' disease is a common autoimmune thyroid disorder, which is responsible for approximately $50-80 \%$ of cases of thyrotoxicosis in Japan. In Graves' disease, the circulating immunoglobulin $\mathrm{G}$ antibodies bind to the G-protein-coupled TSH receptor, and increase thyroid hormone production, causing hyperthyroidism. This disorder shows elevated FT3 and FT4 with suppression of TSH to below the level of detection, as opposed to RTH.

Thus, the coexistence of these two diseases makes the diagnosis and treatment complicated. Here, we describe a rare case of RTH coexisting with Graves' disease, in which the correct diagnosis of RTH was delayed by masking of the signs of SITSH, with final diagnosis due to the inappropriately elevated TSH level after treatment of anti-hyperthyroidism.

\section{Case presentation}

A 30-year-old Japanese man was referred to our hospital because of fatigue, palpitation, body weight loss, finger tremor, and heat intolerance for 3 months. He was $166.2 \mathrm{~cm}$ in height and $60.2 \mathrm{~kg}$ in weight. His blood pressure was $110 / 50 \mathrm{mmHg}$, and his heart rate was 70 beats/minute and regular. His body temperature was $36.3{ }^{\circ} \mathrm{C}$. The thyroid gland was slightly enlarged, non-tender, and softly elastic on palpation. Exophthalmos was not observed. Thyroid function test demonstrated elevated levels of FT3 and FT4, and complete suppression of TSH level, which was below the limit of detection. Serum anti-TSH receptor antibody (TRAb), anti-thyroid peroxidase antibody (TPOAb), and anti-thyroglobulin antibody ( $\mathrm{Tg} A b)$ were positive. Ultrasonography of the thyroid gland revealed diffuse enlargement without tumor lesions. The right and left lobes of the thyroid gland measured $49 \times 24 \times 20 \mathrm{~mm}$ and $54 \times 22 \times 20 \mathrm{~mm}$, respectively. These results indicated that Graves' disease was responsible for primary hyperthyroidism in this case. A diagnosis of Graves' disease was made based on these findings. Methimazole (MMI) therapy was started at $15 \mathrm{mg} /$ day. His symptoms improved gradually, and the dosage of methimazole was decreased as thyroid function normalized. After 6 months, methimazole therapy was continued at $10 \mathrm{mg} /$ day, and the levels of TSH, FT3, and FT4 were maintained within the respective normal ranges. He was transferred to a local hospital. His thyroid function was followed up periodically, and the levels of FT3 and FT4 were elevated, but TSH levels were within normal range or slightly elevated on some occasions. At the age of 48 years, he was referred to our hospital for further endocrinological examination. On physical examination, his height was $165.4 \mathrm{~cm}$, body weight was $58.6 \mathrm{~kg}$, body mass index was $22.1 \mathrm{~kg} / \mathrm{m}^{2}$, blood pressure was $122 / 70 \mathrm{mmHg}$, and his pulse was regular at 80 beats/ minute. His body temperature was $36.8^{\circ} \mathrm{C}$. The thyroid was diffusely enlarged, softly elastic, and non-tender on palpation. Exophthalmos was not observed. Laboratory findings are presented in Table 1 . The results of thyroid function tests with methimazole treatment at $10 \mathrm{mg} /$ day revealed serum levels of FT3, FT4, and TSH of $5.4 \mathrm{pg} / \mathrm{mL}$ (normal range $2.4-4.3 \mathrm{pg} / \mathrm{mL}$ ), $1.7 \mathrm{ng} / \mathrm{dL}$ (normal range $0.9-1.8 \mathrm{ng} / \mathrm{dL}$ ), and $4.77 \mu \mathrm{IU} / \mathrm{mL}$ (normal range $0.35-4.94 \mu \mathrm{IU} / \mathrm{mL}$ ), respectively, indicating SITSH. Chest X-ray and electrocardiographic findings were normal. His bone mineral density was $0.712 \mathrm{~g} /$ $\mathrm{cm}^{2}$ (88\% of the young adult mean) in the femur. He showed no stigmata of thyrotoxicosis. Ultrasonography of the thyroid showed diffuse enlargement of both lobes with no tumor lesions. Increased blood flow was not detected on Color-Doppler imaging (Fig. 1). Thyroid radioactive ${ }^{123}$ I uptake was $11.8 \%$ in 3 hours (reference range, 5-15\%) (Fig. 2). The titer of TRAb was weakly positive, and the dosage of methimazole was decreased gradually to maintain normal TSH level (Fig. 3). Six years after he visited our hospital, methimazole treatment was ceased, and the titer of TRAb became negative. These findings indicated that Graves' disease was in remission. The symptoms of hyperthyroidism, such as finger tremors, palpitations, and weight loss, were not observed. After cessation of methimazole treatment, his thyroid hormone levels fluctuated and showed occasional elevation of FT3 or FT4 with normal TSH level. His state of SITSH persisted. Magnetic resonance imaging (MRI) was performed for the differential diagnosis of TSH producing pituitary tumor, and revealed no tumor lesions. The results of TSH-releasing hormone (TRH) stimulation test are presented in Table 2. His TSH level showed a normal response to TRH stimulation. He was suspected to have RTH. A genetic investigation was conducted with the 
Table 1 Laboratory data on arrival

\begin{tabular}{|c|c|c|c|c|c|c|}
\hline \multicolumn{2}{|l|}{ Urinalysis } & \multicolumn{2}{|c|}{ Biochemistry } & \multicolumn{3}{|c|}{ Endocrinological examination } \\
\hline Color & Yellow & $\mathrm{LDH}$ & $181 \mathrm{IU} / \mathrm{L}$ & $\mathrm{TSH}$ & $4.77 \mu \mathrm{lU} / \mathrm{mL}$ & $(0.35-4.94)$ \\
\hline $\mathrm{pH}$ & 6.5 & ALP & $191 \mathrm{IU} / \mathrm{L}$ & FT3 & $5.4 \mathrm{pg} / \mathrm{mL}$ & $(2.4-4.3)$ \\
\hline Glucose & $(-)$ & $\gamma$-GTP & $33 \mathrm{IU} / \mathrm{L}$ & FT4 & $1.7 \mathrm{ng} / \mathrm{dL}$ & $(0.9-1.8)$ \\
\hline Protein & $(-)$ & CK & $151 \mathrm{IU} / \mathrm{L}$ & $\operatorname{Tg}$ & $3.0 \mathrm{ng} / \mathrm{mL}$ & $(0-33.7)$ \\
\hline Occult blood & $(-)$ & LDL-C & $121 \mathrm{mg} / \mathrm{dL}$ & TRAb & $3.9 \mathrm{IU} / \mathrm{L}$ & $(0-1.0)$ \\
\hline \multirow[t]{2}{*}{ Ketone } & $(-)$ & TG & $146 \mathrm{mg} / \mathrm{dL}$ & TSAb & $269 \%$ & $(0-120)$ \\
\hline & & HDL-C & $48 \mathrm{mg} / \mathrm{dL}$ & $\mathrm{TPO} A b$ & $536 \mathrm{IU} / \mathrm{mL}$ & $(0-16.0)$ \\
\hline Hematology & & $\mathrm{Na}$ & $140 \mathrm{mEq} / \mathrm{L}$ & $\operatorname{Tg} A b$ & $398 \mathrm{IU} / \mathrm{mL}$ & $(0-28)$ \\
\hline WBC & $5600 / \mu \mathrm{L}$ & K & $4.2 \mathrm{mEq} / \mathrm{L}$ & ACTH & $18.4 \mathrm{pg} / \mathrm{mL}$ & $(7.2-63.3)$ \\
\hline RBC & $485 \times 10^{4} / \mu \mathrm{L}$ & $\mathrm{Cl}$ & $102 \mathrm{mEq} / \mathrm{L}$ & cortisol & $9.9 \mu \mathrm{g} / \mathrm{dL}$ & $(4.5-21.1)$ \\
\hline $\mathrm{Hb}$ & $13.5 \mathrm{~g} / \mathrm{dL}$ & $\mathrm{Ca}$ & 9.4 mEq/L & $\mathrm{GH}$ & $0.48 \mathrm{ng} / \mathrm{mL}$ & $(0.13-9.88)$ \\
\hline $\mathrm{Ht}$ & $45.60 \%$ & $P$ & $4.9 \mathrm{mEq} / \mathrm{L}$ & IGF-1 & $127 \mathrm{ng} / \mathrm{mL}$ & $(89-248)$ \\
\hline Plts & $26.4 \times 10^{4} / \mu \mathrm{L}$ & BUN & 16 mg/dL & PRL & $7.72 \mathrm{ng} / \mathrm{mL}$ & $(3.6-12.8)$ \\
\hline CRP & $0.1 \mathrm{mg} / \mathrm{dL}$ & $\mathrm{Cr}$ & $0.7 \mathrm{mg} / \mathrm{dL}$ & $\mathrm{FSH}$ & $6.74 \mathrm{mlU} / \mathrm{mL}$ & $(2.0-8.3)$ \\
\hline TP & $7.5 \mathrm{~g} / \mathrm{dL}$ & UA & $6.7 \mathrm{mg} / \mathrm{dL}$ & $\mathrm{LH}$ & $5.29 \mathrm{mlU} / \mathrm{mL}$ & $(0.8-5.7)$ \\
\hline Alb & $4.5 \mathrm{~g} / \mathrm{dL}$ & FPG & 81 mg/dL & & & \\
\hline T-Bil & $0.47 \mathrm{mg} / \mathrm{dL}$ & $\mathrm{HbA1c}$ & $5.50 \%$ & & & \\
\hline AST & $22 \mathrm{IU} / \mathrm{L}$ & & & & & \\
\hline ALT & $19 \mathrm{IU} / \mathrm{L}$ & & & & & (Normal ra \\
\hline
\end{tabular}

Y-GTP: $\gamma$-glutamyl transpeptidase; ACTH: adrenocorticotropic hormone; Alb: albumin; ALP: alkaline phosphatase; ALT: alanine aminotransferase; AST: aspartate aminotransferase; BUN: blood urea nitrogen; CK: creatine kinase; Cr: creatine; CRP: C-reactive protein; FPG: fasting plasma glucose; FSH: follicle stimulating hormone; FT3: free triiodothyronine; FT4: free thyroxine; GH: growth hormone; $\mathrm{Hb}$ : hemoglobin; HbA1c: glycated hemoglobin; HDL-C: high-density lipoprotein-cholesterol; Ht: hematocrit; IGF-1: insulin-like growth factor-1; LDH: lactate dehydrogenase; LDL-C: low-density lipoprotein-cholesterol; LH: luteinizing hormone; Plts: platelets; PRL: prolactin; RBC: red blood cells; T-Bil: total bilirubin; TG: triglyceride; Tg: thyroglobulin; Tg Ab: anti-thyroglobulin antibody; TP: total protein; TPO Ab: anti-thyroid peroxidase antibody; TRAb: anti-TSH receptor antibody; TSAb: thyroid-stimulating antibody; TSH: thyroid-stimulating hormone; UA: uric acid; WBC: white blood cells
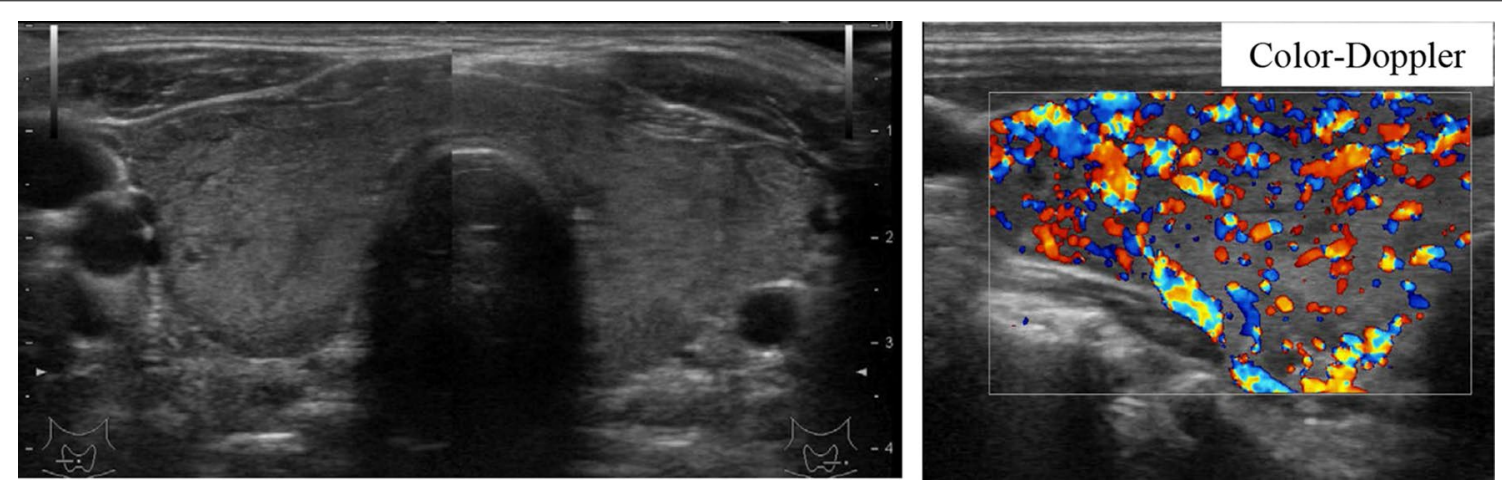

Fig. 1 Thyroid ultrasonography showed diffuse enlargement of both lobes with heterogeneous echogenicity. No tumor lesions were detected. Neither lobe showed increased blood flow on Color-Doppler imaging

patient's written informed consent. Blood samples were obtained, and genomic DNA was isolated from leukocytes. Direct sequencing analysis of the TR $\beta$ gene identified a heterozygous, missense point mutation in exon 8, AGA to AGC, resulting in substitution of arginine by serine at codon 282 (R282S) (Fig. 4). He reported no thyroid disease in his family. Thyroid function tests and DNA analysis were not performed for other family members, because they declined to provide consent.
At the time of writing, he has no signs of thyrotoxic symptoms. His pulse rate is regular at $80-90$ beats/ minute. He is comfortable at rest, and capable in activities of daily living.

\section{Discussion and conclusions}

RTH is a rare autosomal dominant disorder characterized by reduced responsiveness to thyroid hormone, and is estimated to affect approximately 1 per 40,000 


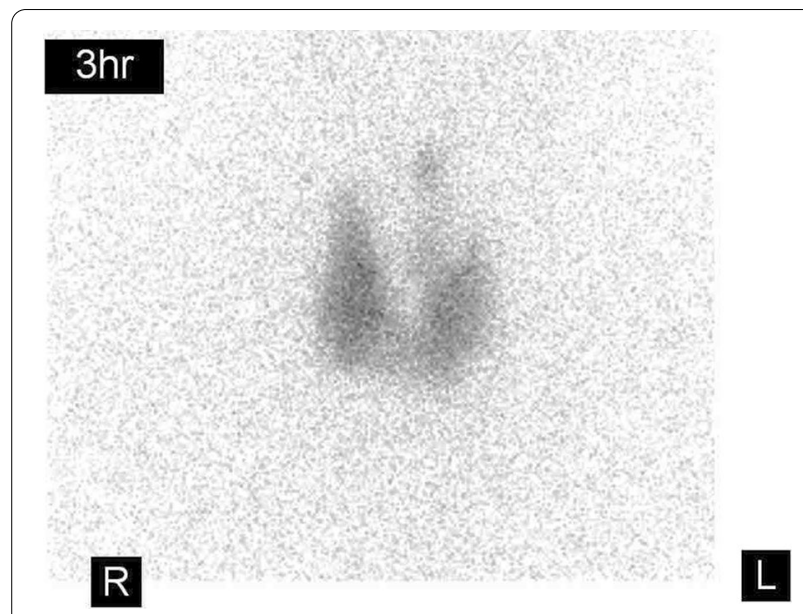

Fig. 2 Thyroid radioactive ${ }^{123}$ I uptake showed no increase. The uptake was $11.8 \%$ in 3 hours (reference range, 5-15\%)

newborn infants [9]. Thyroid hormones have roles in a range of functions, including energy homeostasis, cardiac and gastrointestinal function, and maturation of the central nervous system. These actions are mediated by TRs encoded by two genes: TR $\beta$ and TR $\alpha$. This syndrome is associated with germline mutations of TR $\beta$. TR $\beta$ gene encodes two isoforms by alternative splicing, $\operatorname{TR} \beta 1$ and TR $\beta 2$. TR $\beta 1$ is widely expressed, especially in the liver and kidney. TR $\beta 2$ is expressed in the anterior pituitary and hypothalamus, and mainly contributes to the negative feedback regulation of TSH by thyroid hormone in the anterior pituitary. RTH is associated with genetic mutations in the ligand-binding domain of TR $\beta$, which is common between TR $\beta 1$ and TR $\beta 2$. Thus, mutations of TR $\beta$ cause failure of this negative feedback regulation of TSH by thyroid hormone, and can cause SITSH. The pathogenesis of RTH is related to the distributions of TR $\beta$ and TR $\alpha$ in different tissues, and dominant negative activity of mutant receptors on different target genes. Resistance to thyroid hormone is compensated by increased thyroid hormone levels. Therefore, the patients with RTH have no severe symptoms of hypothyroidism.

Here, we reported a Japanese man with RTH concomitant with Graves' disease. In the onset of Graves' disease, his TSH values were suppressed below the limit of detection. Furthermore, he showed the apparent features of hyperthyroidism, such as general fatigue, palpitation, body weight loss, finger tremor, and heat intolerance. These observations indicated that peripheral tissues were responsive to excess thyroid hormone. Therefore, the

Table 2 Thyrotropin-releasing hormone stimulation test

\begin{tabular}{lllllc}
\hline Time (minutes) & Basal & $\mathbf{3 0}$ & $\mathbf{6 0}$ & $\mathbf{9 0}$ & $\mathbf{1 2 0}$ \\
\hline TSH $(\mu \mid \mathrm{U} / \mathrm{mL})$ & 7.24 & 37.5 & 33.3 & 24.0 & 17.4 \\
FT3 $(\mathrm{pg} / \mathrm{mL})$ & 4.19 & & & & 4.40 \\
PRL $(\mathrm{ng} / \mathrm{mL})$ & 7.16 & 88.03 & 51.12 & 29.90 & 20.89 \\
\hline
\end{tabular}

FT3: free triiodothyronine; PRL: prolactin; TSH: thyroid-stimulating hormone

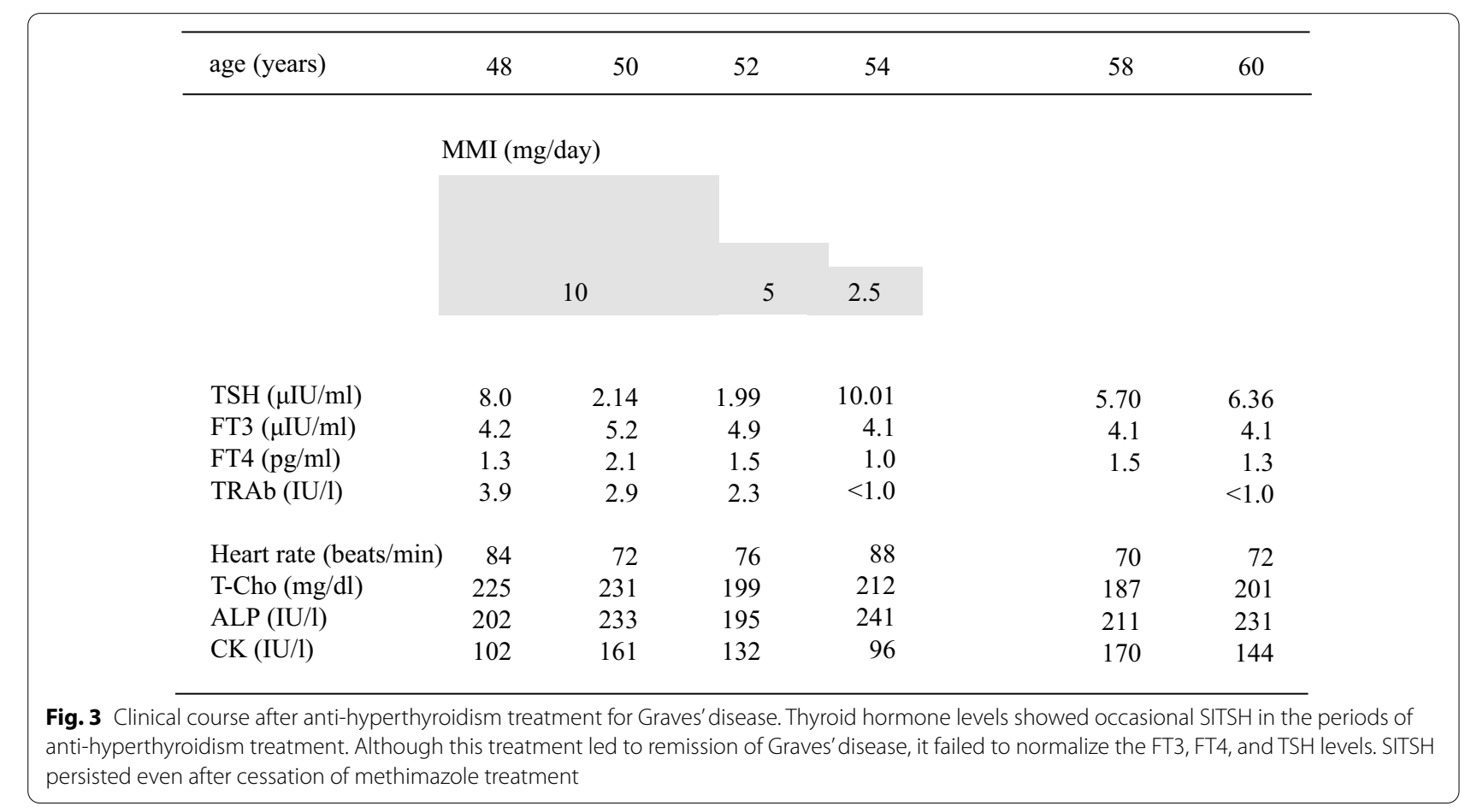




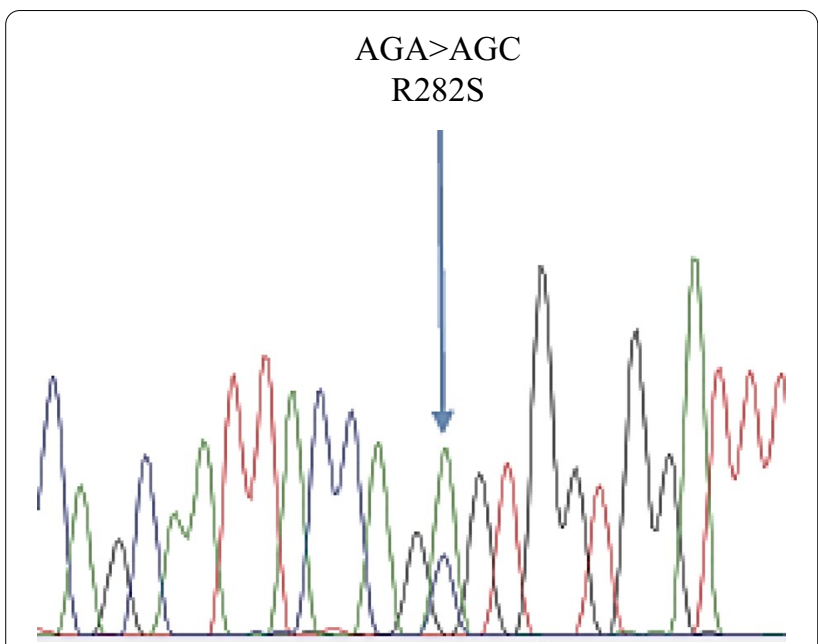

Fig. 4 Direct sequencing analysis of TR $\beta$ gene in genomic DNA extracted from peripheral blood leukocytes. Sequence analysis revealed a heterozygous point mutation in exon 8, AGA to AGC, resulting in substitution of arginine by serine at codon 282 (R282S). The arrow indicates the site of the point mutation

differential diagnosis between Graves' disease alone and Graves' disease coexisting with RTH is very difficult after the onset of hyperthyroidism by Graves' disease. Our case was diagnosed with RTH from the presentation of SITSH after anti-hyperthyroidism treatment. The presentation of SITSH indicates the possibility of RTH or TSHproducing pituitary adenoma [10]. In our case, brain MRI showed no pituitary adenoma, and TRH stimulation test showed a normal response to TSH, thus excluding TSHproducing pituitary adenoma. We analyzed the TR $\beta$ mutations in our case, and the results showed that he carried a heterozygous missense mutation, R282S.

Treatment for Graves' disease with RTH is complicated. Three cases with both Graves' disease and RTH have been reported previously [11-13]. In these cases, as well as our case, anti-thyroid medication was chosen as the initial treatment for Graves' disease. In our case, anti-thyroid medication led to remission of Graves' disease. However, this treatment failed to normalize the FT3, FT4, and TSH levels, due to the failure of the negative feedback regulatory system by RTH. Patients with RTH usually have elevated levels of FT3 and FT4 and normal or slightly elevated TSH level, although the thyroid function before the onset of Graves' disease was unknown in our case. If the levels of FT3 and FT4 are within the normal reference ranges, the patient may have a hypothyroid state. Therefore, the dosage of anti-thyroid medication should be controlled to maintain slightly elevated levels of FT3 and FT4. The relationship between RTH and Graves' disease is unclear. Cases of RTH coexisting with chronic thyroiditis, not only Graves' disease, have been reported [14-16]. It has also been reported that patients with RTH have high prevalence of TPOAb and $\operatorname{TgAb}$, indicating the potential interactions between RTH and autoimmune thyroid disease [17]. Moreover, the hypersecretion of TSH may play an important role in the onset of Graves' disease. TSH has various important actions in the maintenance of normal physiology and in the regulation of immunomodulatory gene expression of thyrocytes. Patients with RTH show elevated production of TSH. It has been reported that the abnormal hypersecretion of TSH in thyrotropin-producing pituitary adenoma can produce anti-idiotype antibodies, causing Graves' disease [18-20]. In our case, the elevated TSH levels due to failure of this negative feedback regulation of TSH by thyroid hormone may have produced TRAb and induced the onset of Graves' disease. The further accumulation of clinical data will be necessary to determine whether germline mutations of TR $\beta$ induce autoimmune thyroid disease in patients with RTH.

In conclusion, we described a rare case of RTH simultaneously existing with Graves' disease. The patient carried a mutation, R282S, in the TR $\beta$ gene. This case indicated some of the difficulties in diagnosis of RTH with coexisting Graves' disease. The diagnosis of RTH did not become apparent until after anti-hyperthyroidism treatment. Careful follow-up is necessary to determine whether secretion of TSH may be inappropriate to regulate thyroid hormone in the periods of antihyperthyroidism treatment. The coexistence of these two diseases should be considered in patients showing occasional SITSH.

\section{Abbreviations \\ Y-GTP: $\gamma$-Glutamyl transpeptidase; ACTH: Adrenocorticotropic hormone; Alb: Albumin; ALP: Alkaline phosphatase; ALT: Alanine aminotransferase; AST: Aspartate aminotransferase; BUN: Blood urea nitrogen; CK: Creatine kinase; CPR: C-peptide immunoreactivity; Cr: Creatine; CRP: C-reactive protein; FPG: Fasting plasma glucose; FSH: Follicle stimulating hormone; FT3: Free trii- odothyronine; FT4: Free thyroxine; GH: Growth hormone; Hb: Hemoglobin; HbA1c: Glycated hemoglobin; HDL-C: High-density lipoprotein cholesterol; $\mathrm{Ht}$ : Hematocrit; IGF-1: Insulin-like growth factor-1; LDH: Lactate dehydrogenase; LDL-C: Low-density lipoprotein cholesterol; LH: Luteinizing hormone; MMI: Methimazole; MRI: Magnetic resonance imaging; Plts: Platelets; PRL: Prolactin; RBC: Red blood cells; RTH: Resistance to thyroid hormone; SITSH: Syndrome of inappropriate secretion of TSH; T-Bil: Total bilirubin; TG: Triglyceride; Tg Ab: Anti-thyroglobulin antibody; TP: Total protein; TPO Ab: Anti-thyroid peroxidase antibody; TR: Thyroid hormone receptor; TRAb: Anti-TSH receptor antibody; TSAb: Thyroid-stimulating antibody; TSH: Thyroid-stimulating hormone; UA: Uric acid; WBC: White blood cells.}

\section{Acknowledgements}

We thank Dr. Yoshitaka Hayashi, Department of Genetics, Division of Stress Adaptation and Protection, Research Institute of Environmental Medicine, Nagoya University, for analysis of the germline mutations of TR $\beta$. 


\section{Authors' contributions}

HA drafted the manuscript. HA and RU performed clinical diagnosis, and treated the patient. RU supervised the writing of the report. All authors read and approved the final manuscript.

\section{Funding}

None.

\section{Availability of data and materials}

All data and materials are available from the corresponding author on reasonable request.

\section{Declarations}

\section{Ethics approval and consent to participate}

Although there is no ethical issue in reporting of this case, ethical approval from the Medical Ethics Committee of Toyama Prefectural Central Hospital is provided.

\section{Consent for publication}

Written informed consent was obtained from the patient for publication of this case report and any accompanying images. A copy of the written consent is available for review by the Editor-in-Chief of this journal.

\section{Competing interests}

The authors declare that they have no competing interests.

\section{Author details}

1 Department of Endocrinology and Metabolism, Toyama Prefectural Central Hospital, 2-2-78 Nishinagae, Toyama-shi, Toyama 930-8550, Japan. ${ }^{2}$ Department of Endocrinology, Diabetology and Metabolism, Toyama Prefectural Rehabilitaion Hospital and Support Center for Children with Disabilities, 36 Shimo-lino, Toyama-shi, Toyama 931-8517, Japan.

\section{Received: 7 August 2020 Accepted: 12 August 2021}

Published online: 25 September 2021

\section{References}

1. Refetoff S, Weiss RE, Usala SJ. The syndromes of resistance to thyroid hormone. Endocr Rev. 1993;14(3):348-9.

2. Refetoff S, Dumitrescu AM. Syndromes of reduced sensitivity to thyroid hormone: genetic defects in hormone receptors, cell transporters and deiodination. Best Pract Res Clin Endocrinol Metab. 2007;21(2):277-305.

3. Usala SJ, Bale AE, Gesundheit N, Weinberger C, Lash RW, Wondisford FE, McBride W, Weintraub BD. Tight linkage between the syndrome of generalized thyroid hormone resistance and the human c-erbA beta gene. Mol Endocrinol. 1988;2(12):1217-20.

4. Parrilla R, Mixson AJ, McPherson JA, McClaskey JH, Weintraub BD. Characterization of seven novel mutations of the c-erbA beta gene in unrelated kindreds with generalized thyroid hormone resistance. Evidence for two "hot spot" regions of the ligand binding domain. J Clin Invest. 1991;88(6):2123-30.
5. Safer JD, Cohen RN, Hollenberg AN, Wondisford FE. Defective release of corepressor by hinge mutants of the thyroid hormone receptor found in patients with resistance to thyroid hormone. J Biol Chem. 1998;273(46):30175-82.

6. Sakurai A, Miyamoto T, Refetoff S, DeGroot LJ. Dominant negative transcriptional regulation by a mutant thyroid hormone receptor-beta in a family with generalized resistance to thyroid hormone. Mol Endocrinol. 1990;4(12):1988-94.

7. Refetoff S, DeWind LT, DeGroot L. Familial syndrome combining deafmutism, stuppled epiphyses, goiter and abnormally high PBI: possible target organ refractoriness to thyroid hormone. J Clin Endocrinol Metab. 1967;27(2):279-94.

8. Weintraub BD, Gershengorn MC, Kourides IA, Fein H. Inappropriate secretion of thyroid-stimulating hormone. Ann Intern Med. 1981;95(3):339-51.

9. Lafranchi SH, Snyder DB, Sesser DE, Skeels MR, Singh N, Brent GA, Nelson JC. Follow-up of newborns with elevated screening T4 concentrations. J Pediatr. 2003;143:296-301.

10. Beck-Peccoz P, Brucker-Davis F, Persani L, Smallridge RC, Weintraub BD. Thyrotropin-secreting pituitary tumors. Endocr Rev. 1996;17(6):610-38.

11. Sivakumar T, Chaidarun S. Resistance to thyroid hormone in a patient with coexisting Graves' disease. Thyroid. 2010;20(2):213-6.

12. Sato H. Clinical features of primary hyperthyroidism caused by Graves' disease admixed with resistance to thyroid hormone (P453T). Endocr J. 2010;57(8):687-92.

13. Ogawa K, Yoshida M, Hayashi Y, Murata Y, Miyata M, Oiso Y. A rare case of resistance to thyroid hormone coexisting with Graves' disease. Endocrine. 2011;40(2):318-9.

14. Fukata S, Brent GA, Sugawara M. Resistance to thyroid hormone in Hashimoto's thyroiditis. N Engl J Med. 2005;352(5):517-8.

15. Aksoy DY, Gurlek A, Ringkananont U, Weiss RE, Refetoff S. Resistance to thyroid hormone associated with autoimmune thyroid disease in a Turkish family. J Endocrinol Invest. 2005;28(4):379-83.

16. Sato $H$, Sakai H. A family showing resistance to thyroid hormone associated with chronic thyroiditis and its clinical features: a case report. Endocr J. 2006:53(3):421-5.

17. Barkoff MS, Kocherginsky M, Anselmo J, Weiss RE, Refetoff S. Autoimmunity in patients with resistance to thyroid hormone. J Clin Endocrinol Metab. 2010;95(7):3189-93.

18. Kamoi K, Mitsuma T, Sato H, Yokoyama M, Washiyama K, Tanaka R, Arai O, Takasu N, Yamada T. Hyperthyroidism caused by a pituitary thyrotrophinsecreting tumour with excessive secretion of thyrotrophin-releasing hormone and subsequently followed by Graves' disease in a middle-aged woman. Acta Endocrinol. 1985;110(3):373-82.

19. Koriyama N, Nakazaki M, Hashiguchi H, Aso K, Ikeda Y, Kimura T, Eto H, Hirano H, Nakano S, Tei C. Thyrotropin-producing pituitary adenoma associated with Graves' disease. Eur J Endocrinol. 2004;151(5):587-94.

20. Kamoun M, d'Herbomez M, Lemaire C, Fayard A, Desailloud R, Huglo D, Wemeau JL. Coexistence of thyroid-stimulating hormone-secreting pituitary adenoma and Graves' hyperthyroidism. Eur Thyroid J. 2014;3(1):60-4.

\section{Publisher's Note}

Springer Nature remains neutral with regard to jurisdictional claims in published maps and institutional affiliations.

Ready to submit your research? Choose BMC and benefit from:

- fast, convenient online submission

- thorough peer review by experienced researchers in your field

- rapid publication on acceptance

- support for research data, including large and complex data types

- gold Open Access which fosters wider collaboration and increased citations

- maximum visibility for your research: over 100M website views per year

At BMC, research is always in progress.

Learn more biomedcentral.com/submissions 